\title{
Training on Creating Interactive Learning Media to Strengthen Integer and Fractional Material for Primary School Teachers of Teacher Working Group IV, X Koto Singkarak
}

\author{
Dewi Murni, H Helma, Riry Sriningsih \\ Jurusan Matematika FMIPA Universitas Negeri Padang, Padang, Sumatera Barat, Indonesia \\ * Correspondence: dewimurni_mat@fmipa.unp.ac.id; Tel.: +62-852-651-74778
}

Diterima 5 November 2019, Disetujui 21 Maret 2020, Dipublikasikan 31 Maret 2020

\begin{abstract}
The thinking phase of students at primary school level is in a concrete operational phase, so that during learning they will more easily understand whether they use the media that they see and do directly. Based on observations and discussions with various primary school teachers, especially for integer and fraction, most teachers did not use a good learning media when teaching. This is because the teacher is not used to and trained in creating and using interactive learning media. As a result, students still have difficulty in understanding integer and fraction operations. To solve these problems, the community service team has provided training to primary school teachers to create interactive learning media and to practice the use of these media. The results of the training have been able to improve the competence of teachers, namely the understanding and skills of teachers in creating interactive media and applying it in learning integer numbers and fractions
\end{abstract}

Keywords - Interactive Learning Media, Integer, Fractional, Primary school

\section{Pendahuluan}

Berdasarkan hasil observasi pendahuluan dan diskusi kepada beberapa guru SD di Kecamatan $\mathrm{X}$ Koto Singkarak, diketahui bahwa sebagian besar dari mereka dalam mengajarkan konsep matematika, masih mengandalkan buku paket berisi gambar-gambar sebagai media pembelajaran. Hal ini, membuat siswa SD kurang tertarik untuk mempelajari matematika, karena tahap berpikir siswa SD masih dalam tahap berpikir konkrit, sehingga mereka lebih cepat memahami konsep jika menggunakan media konkrit yang dapat mereka manipulasi sendiri. Selain itu media konkrit juga dapat menambah antusias mereka untuk belajar karena belajar dengan media membuat mereka belajar sambil bermain. Pengenalan konsep pada peserta didik kelas rendah sangatlah penting, oleh karena itu penggunaan media harus dipilih guru sesuai dengan materi yang diajarkan.

Menurut Ariesandi dalam Firenty (2011), mengungkapkan bahwa urutan pengenalan matematika yang baik kepada anak adalah: 1) belajar menggunakan benda konkrit/nyata, 2) belajar membuat bayangan pikiran, dan 3) belajar menggunakan simbol. Lebih jauh lagi dijelaskan bahwa jika ingin mendapatkan hasil yang baik sebaiknya proses tersebut dilalui tahap demi tahap dan jangan ada satupun proses yang terlewati. Jika ada tahapan yang dilewati, pada suatu saat si anak harus membentuk konsep sendiri dari awal.

Kehadiran media dalam proses belajar mengajar mempunyai arti yang cukup penting. Karena dalam kegiatan tersebut, ketidakjelasan bahan yang disampaikan dapat dibantu dengan menghadirkan media sebagai perantara. Kerumitan bahan yang akan disampaikan kepada 
siswa dapat disederhanakan dengan bantuan media. Media dapat mewakili hal-hal yang kurang mampu guru ucapkan melalui kata-kata atau kalimat tertentu. Bahkan keabstrakan bahan dapat dikonkretkan dengan kehadiran media sehingga siswa lebih mudah mencerna dan memahami materi dengan baik.

Menurut Sadiman 1986 dalam masyarakatbelajar.wordpress.com (2009), faktorfaktor yang perlu dipertimbangkan dalam pemilihan media pembelajaran adalah a) tujuan instruksional yang ingin dicapai, b) karakteristik pembelajar atau sasaran, c) jenis rangsangan belajar yang diinginkan (audio visual, gerak, atau lainnya), d) kondisi lingkungan setempat, e) luasnya jangkauan yang ingin dilayani, f) ketersediaan sumber setempat, g) ketersediaan dana, tenaga, h) fasilitas untuk memproduksi atau membeli, i) faktor keluesan, kepraktisan, dan ketahanan dalam waktu tertentu, dan j) efektifitas biaya dalam jangka waktu yang panjang.

Disamping pemilihan media yang tepat, peran guru sangatlah diperlukan dalam proses pembelajaran. Guru berperan dalam melatih dan membimbing siswa dalam mengasah dan mengembangkan pola pikirnya. Untuk mewujudkan hal tersebut, guru harus mampu merencanakan proses belajar mengajar yang baik. Guru mempunyai tugas untuk memilih model, metode dan media pembelajaran yang tepat sesuai dengan materi yang disampaikan demi tercapainya tujuan pendidikan.

Berdasarkan hasil diskusi yang dilakukan dengan guru, diperoleh bahwa: 1) Pada umumnya, guru belum menggunakan media pembelajaran yang interaktif dalam menjelaskan materi khususnya operasi penjumlahan, pengurangan, perkalian, dan pembagian (kabataku) pada bilangan bulat dan pecahan, sehingga siswa sulit untuk memahaminya, 2) Guru belum memfasilitasi berbagai gaya belajar siswa, 3) Anggapan siswa terhadap mata pelajaran matematika yang sulit (penuh dengan angka dan simbol), sehingga mereka fobi dengan matematika, 4) Guru memerlukan pemantapan pemanfaatan media pembelajaran dalam menjelaskan operasi kabataku pada bilangan bulat dan pecahan sesuai dengan materi dan karakteristik siswa, 5) Guru memerlukan pelatihan bagaimana cara merancang dan membuat media pembelajaran yang interaktif dan bisa menarik minat siswa untuk belajar materi operasi kabataku pada bilangan bulat dan pecahan, sehingga siswa tidak lagi fobi dengan matematika dan dapat dengan mudah memahami materi dengan baik, 6) Guru memerlukan pelatihan penggunaan media pembelajaran yang sudah dibuat dalam menjelaskan materi operasi kabataku pada bilangan bulat dan pecahan kepada siswa sehingga siswa senang belajar matematika.

Secara umum, identifikasi dari permasalahan yang terjadi adalah guru mengalami kesulitan menyusun pembelajaran yang terurut yang berawal dari konsep konkret (enaktif), gambar (ikonik), dan abstrak (simbolik). Hal ini terbukti dari hasil observasi, dan wawancara yang tim lakukan, yaitu pembelajaran yang berlangsung di kelas ataupun buku-buku yang digunakan masih berisi gambar dan simbol-simbol saja (tahap ikonik dan simbolik). Jarang guru menggunakan media yang konkrit. Oleh karena itu, kami tim pengabdian ingin membantu guru dalam mengatasi permasalahn tersebut, yaitu bagaimana cara mengajarkan matematika kepada anak secara nyata bukan abstrak.

Untuk mencapai hal tersebut, guru harus mampu merencanakan pembelajaran sesuai dengan karakteristik dan tahap berpikir siswa. Dalam hal ini siswa diminta dapat melakukan manipulasi yaitu melakukan aktivitas-aktivitas seperti menemukan konsep, prinsip dan prosedur penyelesaian masalah. Guru harus mampu membuat dan menggunakan media pembelajaran yang lebih menarik dan mudah digunakan siswa. Hal ini menjadikan siswa lebih memahami konsep dasar operassi bilangan bulat dan pecahan yang merupakan dasar untuk materi berikutnya. Agar siswa dapat melakukan aktivitas-aktivitas yang kreatif, maka guru harus merencanakan dan menyiapkan perangkat pembelajaran sebaik mungkin. Sebagai contoh, menyiapkan bermacam-macam media pembelajaran yang lebih menarik dan mudah digunakan siswa.

Agar guru dapat memilih dan membuat media yang cocok dengan kondisi anak didiknya maka guru SD perlu diberi pelatihan untuk memantapkan materi matematika khususnya 
materi bilangan bilangan bulat dan pecahan (penjumlahan, pengurangan, perkalian, dan pembagian) menggunakan media pembelajaran matematika yang interaktif.

Menurut feryferdiansyah dalam mediapembelajaran-matematika (2012) mengapa pembelajaran matematika memerlukan media, : (1)Objek matematika itu abstrak sehingga memerlukan peragaan;(2)Sifat materi matika tidak mudah dipahami;(3) Hirarkhi matematika ketat dan kaku;(4)Aplikasi matematika kurang nyata;(5)Belajar matematika perlu focus; (6)Citra pembelajaran matematika kurang baik

\section{Hasil dan Diskusi}

Berdasarkan tujuan, target dan luaran kegiatan pengabdian yang telah ditetapkan, secara umum hasil kegiatan pelatihan ini adalah:

1. Terjadinya peningkatan pemahaman guru terhadap proses pembelajaran aktif yaitu bagaimana mengaktifkan siswa agar menemukan sendiri konsep-konsep untuk operasi bilangan bilangan bulat dan operasi pecahan,

2. Terjadinya peningkatan keterampilan guru dalam merancang dan membuat media pembelajaran matematika yang interaktif khususnya materi operasi bilangan bulat dan pecahan, dan mampu menggunakan media interaktif tersebut, sehingga dapat diterapkan dalam proses pembelajaran matematika di kelas. Pada materi bilangan bulat, media yang sudah dirancang dan dibuat adalah media yang berbentuk lempengan positif dan lempengan negatif. Media tersebut dibuat dari kertas karton manila berwarna merah $(+)$ dan hitam (-). Pemanfaatan media ini adalah untuk menemukan jumlah dua bilangan positif, jumlah bilangan positif dan negative juga menjumlah dua bilangan negative. Pada materi pecahan, media yang sudah dirancang dan dibuat adalah media yang berbentuk lingkaran. Media tersebut dibuat dari plastic transparan yang berwarna-warni. Pemanfaatan media ini adalah untuk menanamkan konsep pecahan kepada siswa, khususnya pecahan senilai, membanding dua pecahan, penjumlahan pecahan dengan penyebut sama dan penyebut yang tidak sama,

3. Menghasilkan media interaktif untuk operasi bilangan bulat dan pecahan,

Kegiatan yang dilaksanakan dimulai dari presentasi tentang jenis-jenis media interaktif yang dapat digunakan dalam menjelaskan konsep matematika kepada anak di kelas, bagaimana cara merancang dan membuat beberapa media interaktif pada materi bilangan bulat dan pecahan serta berlatih bagaimana cara menggunakannya dalam proses pembelajaran di kelas. Hal ini berakibat pada peningkatan pemahaman, wawasan dan keterampilan guru dalam menggunakan media interaktif untuk menjelaskan konsep bilangan bulat dan pecahan kepada anak secara konkrit di kelas dan anakpun menjadi lebih mudah memahami konsep matematika yang dijelaskan guru.

Kegiatan pelatihan yang dilakukan pada hari pertama setelah pembukaan oleh kepala UPT dan ketua KKG IV Kecamatan IX koto Singkarak Kabupaten Solok adalah presentasi tentang jenis-jenis media interaktif yang dapat digunakan guru dalam membantu menjelaskan konsep matematika kepada anak sehingga anak lebih mudah memahami materi dengan baik. Kemudian dilanjutkan dengan merancang dan membuat media interaktif materi operasi bilangan bulat: jumlah dua bilangan bulat positif, jumlah bilangan bulat positif dengan bilangan bulat negative dan jumlah dua bilangan bulat negatif dari karton manila yang berwarna merah dan hitam. Setelah jam istirahat, guru-guru dilatih menggunakan media (alat manipulative) yang sudah dibuat untuk mencari hasil operasi jumlah bilangan bulat. Berikut ini contoh alat manipulatif yang dibuat guru pada Kegiatan 1. 


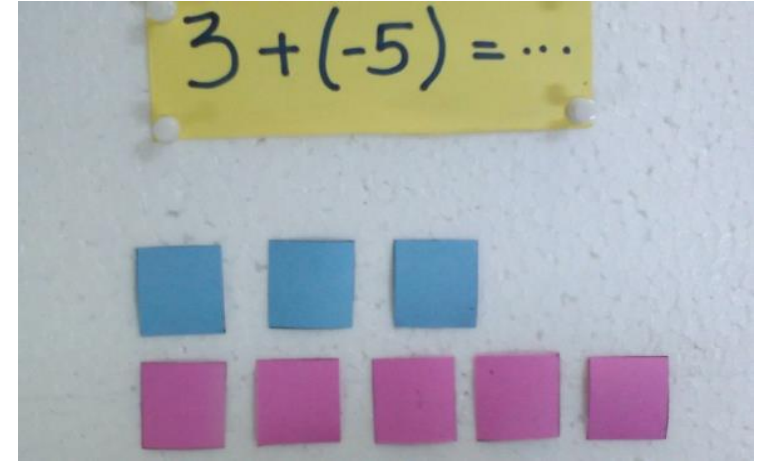

Gambar 1. Contoh untuk menghitung jumlah dua bilangan bulat

Kegiatan pelatihan pada hari kedua, guru-guru melakukan kegiatan membuat media interaktif untuk konsep pecahan. Guru membuat beberapa lingkaran yang berisi beberapa pecahan seperti pecahan seperdua, sepertiga, seperempat, seperenam , seperlapan dan seperduabelas. Kemudian guru memahami konsep pecahan seperempat adalah bahwa satu lingkaran dibagi empat sama besar. Kemudian guru memperlihatkan bagaimana membanding dua pecahan
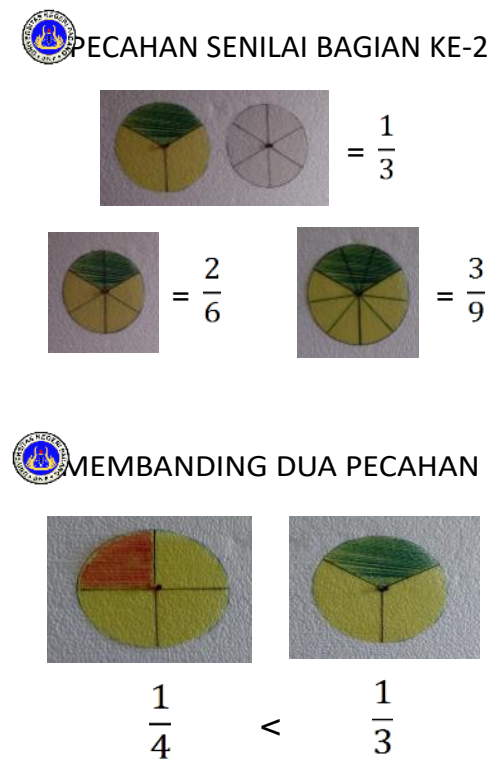

Gambar 2. Contoh untuk pemahaman kosep pecahan senilai dan membanding

Kegiatan pelatihan pada hari ke tiga yaitu merancang dan membuat alat manipulative untuk materi pecahan yang berupa lingkaran. Lingkaran dibuat pada plastic transparan menggunakan spidol permanen dan spidol non permanen yang berwarna-warni.
Alat manipulative ini digunakan untuk menjelaskan konsep pecahan senilai dan penjumlahan pecahan. Berikut ini contoh alat manipulative yang dibuat guru pada kegiatan 4 .

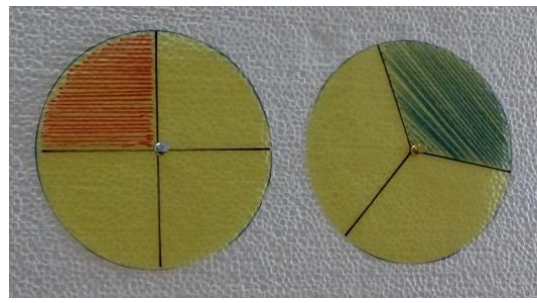

Gambar 3. Contoh penjumlahan pecahan

Kegiatan pelatihan pada hari ke empat yaitu merancang dan membuat alat media interaktif untuk menentukan perkalian dua pecahan seperti duapertiga dikali empat per lima, maka dengan media maka nantinya anak didik akan bisa sendiri menentukan hasil dengan melihat hasilnya secara konkrit. Media dibuat dari kertas transparan yang dibagi-bagi secara mendatar dan secara horizontal. Media yang dibagi mendatar sebagai bilangan pecahan pertama dan media yang dibagi mendatar menjadi pecahan kedua yang akan dikali.

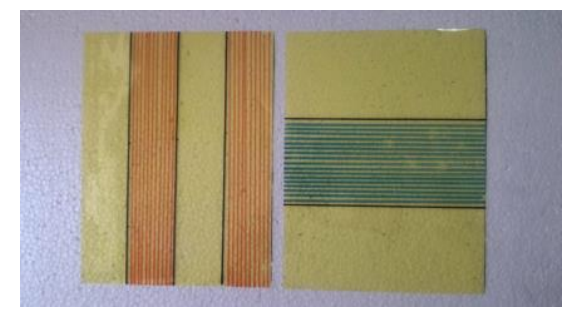

Gambar 4. Contoh untuk perkalian dua pecahan

Kegiatan pelatihan yang sudah dilakukan perlu ditelaah kebermaknaannya sesuai dengan tujuan kegiatan. Hal ini dilakukan dengan cara memberikan angket kepada peserta pelatihan pada pertemuan terakhir. Tujuan pemberian angket ini adalah untuk mengetahui tanggapan peserta terhadap pelaksanaan kegiatan dan hasil yang dirasakan, sekaligus memberikan saran untuk kegiatan-kegiatan pengabdian selanjutnya.

Secara umum, terdapat tiga indikator yang ditelaah, yaitu: 1) peningkatan pemahaman materi (0perasi bilangan bulat dan pecahan), 2) peningkatan keterampilan dalam membuat media interaktif, dan 3) kemahiran dalam menggunakan media interaktif. Lembaran angket yang diberikan kepada peserta pelatihan menggunakan Skala 
Likert dengan menggunakan empat pilihan sangat setuju (SS), setuju (S), tidak setuju (TS), dan sangat tidak setuju (STS). Hasil analisis terhadap angket peserta pelatihan dapat digambarkan tanggapan peserta untuk setiap indikator.

\section{Indikator Peningkatan Pemahaman Materi (operasi bilangan bulat dan pecahan)}

Pada indikator pertama ada empat hal yang dicapai melalui kegiatan pelatihan ini,yaitu:

1)Kegiatan pelatihan dapat meningkatkan pemahaman saya tentang operasi bilangan bulat dan pecahan ;2) Guru telah memiliki wawasan dalam memilih media interaktif yang digunakan untuk menyampaikan materi bilangan bulat dan pecahan dalam pembelajaran matematika; 3) Guru telah mengetahui langkah-langkah dalam membuat media untuk materi pembelajaran ; 4) Guru mengetahui langkah-langkah pembuatan media yang sesuai dengan konsep materi

Secara umum kegiatan pelatihan telah dapat meningkatkan pemahaman guru tentang pembuatan media untuk materi bilangan bulat dan pecahan. Pada materi bilangan bulat guru sudah mampu menjelaskan dengan mudah dan menarik operasi bilangan bulat dan menemukan hasil operasi bilangan bulat menggunakan media, seperti : $-3-(-7), 3-(-7)$. Pada materi pecahan, guru sudah mampu menjelaskan dengan mudah menggunakan media lingkaran yang terbuat dari transparan, untuk menjelaskan operasi pecahan senilai, membanding dua pecahan dan penjumlahan pecahan dengan menggunakan media interaktif yang sudah dibuat. Disamping itu, guru juga mendapatkan tambahan wawasan dalam memilih media interaktif yang sesuai dengan karakteristik siswa untuk menyampaikan materi geometri dan pecahan dalam pembelajaran matematika. Hal ini terlihat, ada sebesar 70,8\% guru menjawab sangat setuju dan $29,2 \%$ guru menjawab setuju.

\section{Peningkatan Keterampilan dalam Membuat Media Interaktif}

Pada indikator kedua ada tiga hal yang telah dicapai melalui kegiatan pelatihan ini, yaitu: 1) Kegiatan pelatihan dapat meningkatkan keterampilan guru dalam membuat dan menggunakan media pembelajaran untuk operasi bilangan bulat dan pecahan ;2) Guru dapat menggunakan langkah-langkah dalam membuat media untuk materi operasi bilangan bulat dan pecahan ;3) Guru dapat merancang dan membuat media yang sesuai dengan konsep operasi bilangan bulat dan pecahan.

Berdasarkan hasil angket yang diberikan dapat disimpulkan bahwa pelatihan ini memberikan manfaat bagi guru, yaitu meningkatkan keterampilan guru dalam membuat dan menggunakan media pembelajaran operasi bilangan bulat dan pecahan, mengetahui langkahlangkah dalam membuat media untuk materi, dapat menambah wawasan guru tentang variasi media interaktif yang dapat digunakan untuk membantu guru dalam menjelaskan materi dengan mudah serta dapat dipahami siswa dengan baik. Hal ini terlihat dari jawaban guru yang menjawab pada skala likert sangat setuju $38,8,8$ $\%$ dan setuju $61,2 \%$.

\section{Kemahiran dalam Meggunakan Media Interaktif}

Pada indikator ketiga juga ada tiga hal yang telah dicapai melalui kegiatan pelatihan ini,

1)Guru optimis dapat menggunakan keterampilan yang telah diperoleh untuk menanamkan konsep operasi bilangan bulat dan pecahan; 2) Guru optimis dapat membuat pembelajaran operasi bilangan bulat dan pecahan. lebih menarik dengan media yang telah dibuat sendiri ; 3) Guru akan menggunakan hasil pelatihan ini untuk meningkatkan kompetensi saya dalam berkarya Dapat disimpulkan bahwa pelatihan ini telah mampu menjadikan guru mahir membuat media pembelajaran. Hal ini terlihat dari jawaban guru yang hanya menjawab pada skala likert sangat setuju 57,4\% dan setuju.42,6\%.

\section{B. Pembahasan}

Berdasarkan pengamatan selama pelaksanaan pelatihan diketahui bahwa guru-guru sangat memerlukan kegiatan yang dapat menambah keterampilan msreka dalam membuat media pembelajaran yang dapat meningkatkan motivasi dan keaktifan siswa dalam belajar. Khusus untuk materi matematika penggunaan media pembelajaran sangat membantu guru untuk menanamkan konsep kepada siswa SD. 
Dengan bahan-bahan yang sederhana dan relatif murah guru dapat membuat media pembelajaran yang cukup menarik untuk dikerjakan siswa dalam rangka penanam konsep operasi bilangan bulat dan pecahan.

Banyak cara dan upaya untuk dapat meningkatkan kompetensi dan profesionalisme guru. Salah satu cara yang seharusnya dilakukan guru adalah melakukan peningkatan keterampilan dalam merancang, membuat dan menggunakan media pembelajaran yang bervariasi, menarik, dan sesuai dengan karakteristik siswa. Praktik pembelajaran dengan menggunakan media interaktif dapat membantu (1) pengembangan kompetensi guru dalam menyelesaikan masalah pembelajaran, (2) peningkatan kompetensi kepribadian, sosial, dan profesional guru, dan (3) siswapun lebih mudah memahami materi pelajaran matematika dengan baik.

Secara umum hasil kegiatan pelatihan ini adalah media interaktif yang berupa alat manipulative. Kegiatan ini dilaksanakan dalam bentuk sharing informasi dari para Dosen Jurusan Matematika FMIPA UNP. Kemudian diikuti dengan Pelatihan Pemantapan Materi operasi bilangan bulat dan pecahan kepada Guru-guru Sekolah Dasar Kelompok Kerja Guru (KKG) Gugus IV Kec. X Koto Singkarak, Kab. Solok yang terdiri dari 9 sekolah.

Metode yang digunakan dalam kegiatan pelatihan ini terdiri atas tiga bagian yaitu penyajian teori tentang Konsep operasi bilangan bulat dan pecahan., praktik pembuatan media interaktif operasi bilangan bulat, pecahan senilai dan penjumlahan pecahan), serta praktik menggunakan media interaktif tersebut untuk menjelaskannya kepada anak di kelas nantinya.

Berdasarkan analisis terhadap angket yang diberikan, dengan adanya kegiatan pelatihan ini guru merasa termotivasi dan optimis untuk dapat merancang, membuat dan menggunakan media interaktif di kelas dan terjawab kesulitan selama ini bagaimana cara mengajarkan konsep rumus luas daerah bidang datar, operasi bilangan bulat, pecahan senilai dan penjumlahan pecahan. Guru merasa mendapat pengetahuan dan wawasan tentang hal yang berkaitan dengan bagaimana merancang dan membuat media pembelajaran bilangan bulat dan pecahan yang mudah dan menarik bagi siswa.

Pada pelaksanaan kegiatan pelatihan ini terdapat kesan dan saran peserta pelatihan yang dirangkum dari angket yang diberikan kepada peserta pada akhir kegiatan pengabdian kepada masyarakat yang tim lakukan dan dipaparkan sebagai berikut. Kesan yang disampaikan oleh peserta pelatihan tersebut adalah (a) kegiatan ini menambah wawasan dan keterampilan peserta dalam merancang, membuat dan menggunakan media interaktif khususnya materi geometri bangun datar dan bilangan (bulat dan pecahan), (b) peserta menjadi termotivasi dalam memberikan pembelajaran matematika yang bervariasi kepada siswanya dengan media interaktif yang sudah dipelajari sehingga siswa tidak merasa bosan untuk belajar matematika dan lebih mudah memahaminya, dan (c) peserta merasa terbantu dalam mengatasi kesulitannya selama ini untuk mengajarkan konsep operasi bilangan bulat dan pecahan.Adapun saran untuk kegiatan ini adalah (a) Pembuatan media tambahan untuk materi matematika yang lain dan (b) pelatihan yang diberikan berkelanjutan untuk tahun-tahun berikutnya untuk masalah-masalah lain yang dihadapi guru dalam PBM.

\section{Pustaka}

[1] Abdullah S, Wakiman, T. Anggraini G. 2000. Materi Pembinaan Guru SD di Daerah. Yogyakarta: PPG Matematika

[2] Boggan, M., S. Harper and A. Whitmire. Using manipulative to teach elementery mathematic. Jurnal of Instruksional Pedagogies. Vol 3 (10)

[3] Cecil, dkk. Pengembangan Perangkat Pembelajaran pada Materi Geometri dan Pengukuran dengan Pendekatan Pendidikan Matematika Realistik Indonesia di SD Negeri 179 Palembang. Jurnal Pendidikan Matematika Vol. 3 No. 2 Des 2009

[4] Dwina, Fitrani dan Riry Sriningsih. 2016. Pengembangan Pembelajaran Matematika Menggunakan Alat Maniulatif Pada Sekolah Dasar Berbasis Lesson Study. Penelitian Hibah Bersaing, Simlitabmas

[5] Sriningsih, Riry; Murni, Dewi; Helma, 
Helma. Peningkatan Keterampilan Guru Sekolah Dasar Menggunakan Media Interaktif Untuk Materi Geometri Dan Pecahan. Pelita Eksakta, [S.L.], V. 1, N. 1, P. 15-19, Mar. 2018. Issn 2615-0719.

[6] Siti Khomsatun. 2010. Penggunaan Media Pembelajaran Kartu. Fakultas Keguruan dan Ilmu Pendidikan Matematika Universitas Muhammadiyah Purwokerto

[7] Uttal, D.H., K.V. Scudder and J.S. Deloache. 1997. Manipulative as symbols: A new Perspective on the Use of Concrete Object to Teach Mathematics. Abblex Publishing Corporation

https://indrianiblog.wordpress.com/2012/03/10

teori-belajar-mengajar-matematika-sekolah-

dasar/

https://masyarakatbelajar.wordpress.com/2009/ 10/21/fungsi-dan-manfaat-media-pengajaran/

https://masyarakatbelajar.wordpress.com/2009/ 10/17/perencanaan-pemilihan-mediapembelajaran/ http://feryferdiansyah16.blogspot.com/2012/09 /media-pembelajaran-matematika.html 